\title{
Bietti crystalline dystrophy
}

INSERM

\section{Source}

INSERM. (1999). Orphanet: an online rare disease and orphan drug data base. Bietti crystalline dystrophy. ORPHA:41751

Bietti's crystalline dystrophy $(B C D)$ is a rare progressive autosomal recessive tapetoretinal degeneration disease, occurring in the third decade of life, characterized by small sparkling crystalline deposits in the posterior retina and corneal limbus in addition to sclerosis of the choroidal vessels and manifesting as nightblindness, decreased vision, paracentral scotoma, and, in the end stages of the disease, legal blindness. 